\title{
ARTICLE
}

\section{Flexible lithium-oxygen battery based on a recoverable cathode}

\author{
Qing-Chao Liu ${ }^{1,2, \star}$, Ji-Jing $X u^{1, \star}$, Dan $X u^{1} \&$ Xin-Bo Zhang ${ }^{1}$
}

Although flexible power sources are crucial for the realization next-generation flexible electronics, their application in such devices is hindered by their low theoretical energy density. Rechargeable lithium-oxygen $\left(\mathrm{Li}-\mathrm{O}_{2}\right)$ batteries can provide extremely high specific energies, while the conventional $\mathrm{Li}-\mathrm{O}_{2}$ battery is bulky, inflexible and limited by the absence of effective components and an adjustable cell configuration. Here we show that a flexible $\mathrm{Li}-\mathrm{O}_{2}$ battery can be fabricated using unique $\mathrm{TiO}_{2}$ nanowire arrays grown onto carbon textiles (NAs/CT) as a free-standing cathode and that superior electrochemical performances can be obtained even under stringent bending and twisting conditions. Furthermore, the $\mathrm{TiO}_{2} \mathrm{NAs} / \mathrm{CT}$ cathode features excellent recoverability, which significantly extends the cycle life of the $\mathrm{Li}-\mathrm{O}_{2}$ battery and lowers its life cycle cost.

\footnotetext{
${ }^{1}$ State Key Laboratory of Rare Earth Resource Utilization, Changchun Institute of Applied Chemistry, Chinese Academy of Sciences, Changchun 130022, China. ${ }^{2}$ School of Materials Science and Engineering, Jilin University, Changchun 130012, China. * These authors contributed equally to this work. Correspondence and requests for materials should be addressed to X.-B.Z. (email: xbzhang@ciac.ac.cn).
} 
T he worldwide demand for flexible electronics continues to grow rapidly because of their special advantages such as being lightweight, bendable, rugged, portable, rollable and potentially foldable, which have revolutionized several industries ranging from consumer products to the automotive, aerospace and medical industries ${ }^{1-5}$. To achieve a 'flexible electronics' society, well-matched flexible energy storage/ conversion devices are recognized as one of the key required components. However, current conventional power sources are too rigid and bulky to be integrated into flexible devices. Several inspirational prototypes have been developed in response including flexible lithium-ion batteries ${ }^{6-10}$, supercapacitors ${ }^{11-15}$ and solar cells ${ }^{16-19}$. However, the low theoretical energy density of these components intrinsically limits their application in next-generation flexible devices. Fortunately, rechargeable lithium-oxygen $\left(\mathrm{Li}-\mathrm{O}_{2}\right)$ batteries have emerged as one of the most promising electrochemical energy storage technologies because of their exceptionally high theoretical energy density of $3,600 \mathrm{Wh} \mathrm{kg}^{-1}$ (refs 20-24). Although the development of a flexible $\mathrm{Li}-\mathrm{O}_{2}$ battery could theoretically meet the urgent demand for a high energy density battery in flexible devices, because this technology is still in its early stages, numerous scientific and technological challenges must first be overcome for the conventional Li- $\mathrm{O}_{2}$ battery, much less the flexible type. First, the carbon cathode is problematic because the decomposition of carbon material and its promotional effect on electrolyte decomposition leads to carbon cathode passivation and premature battery death ${ }^{25,26}$. Second, the highly conductive current collector, which includes metal foam and carbon paper, is inflexible. Finally, the cell configuration of conventional $\mathrm{Li}-\mathrm{O}_{2}$ batteries (either the coin cell or Swagelok design) is exclusively packed with bulky and rigid stainless steel or engineering plastic. Therefore, there is an urgent need to first design and fabricate mechanically robust, electrochemically stable and highly effective components, as well as create a preferable cell configuration and structural design on the path toward flexible $\mathrm{Li}-\mathrm{O}_{2}$ batteries.

We report a strategy to fabricate a flexible, free-standing and recoverable cathode by the seeds-assisted construction of unique hierarchical rutile $\mathrm{TiO}_{2}$ nanowire arrays $\left(\mathrm{TiO}_{2} \mathrm{NAs}\right)$ grown onto carbon textiles (CT). A highly flexible $\mathrm{Li}-\mathrm{O}_{2}$ battery with excellent mechanical strength and superior electrochemical performance, including a high round-trip efficiency, good rate capability and cycling stability, was fabricated by employing $\mathrm{TiO}_{2}$ NAs/CT as both a new class of cathode and current collector to replace the conventional rigid and bulky counterparts. Furthermore, we found that $\mathrm{TiO}_{2}$ NAs/CT exhibits excellent

a

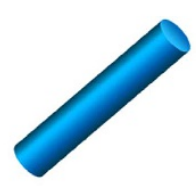

CF

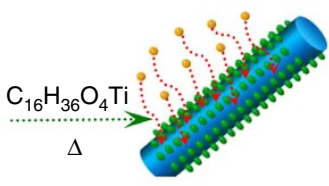

Partly coated $\mathrm{TiO}_{2} \mathrm{~S} / \mathrm{CF}$

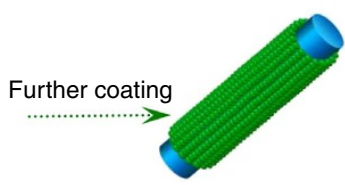

Densely covered $\mathrm{TiO}_{2} \mathrm{~S} / \mathrm{CF}$

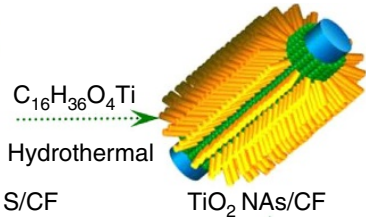

$\mathrm{TiO}_{2} \mathrm{NAs} / \mathrm{CF}$ In situ modification

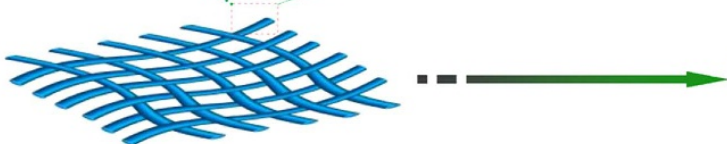

CT

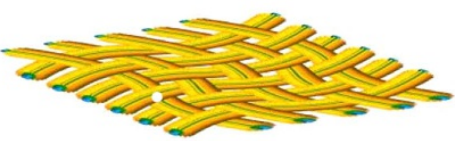

$\mathrm{TiO}_{2} \mathrm{NAs} / \mathrm{CT}$

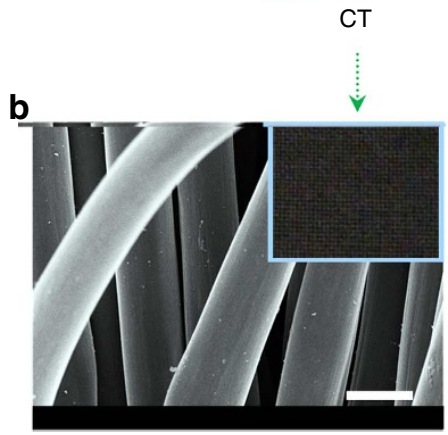

C
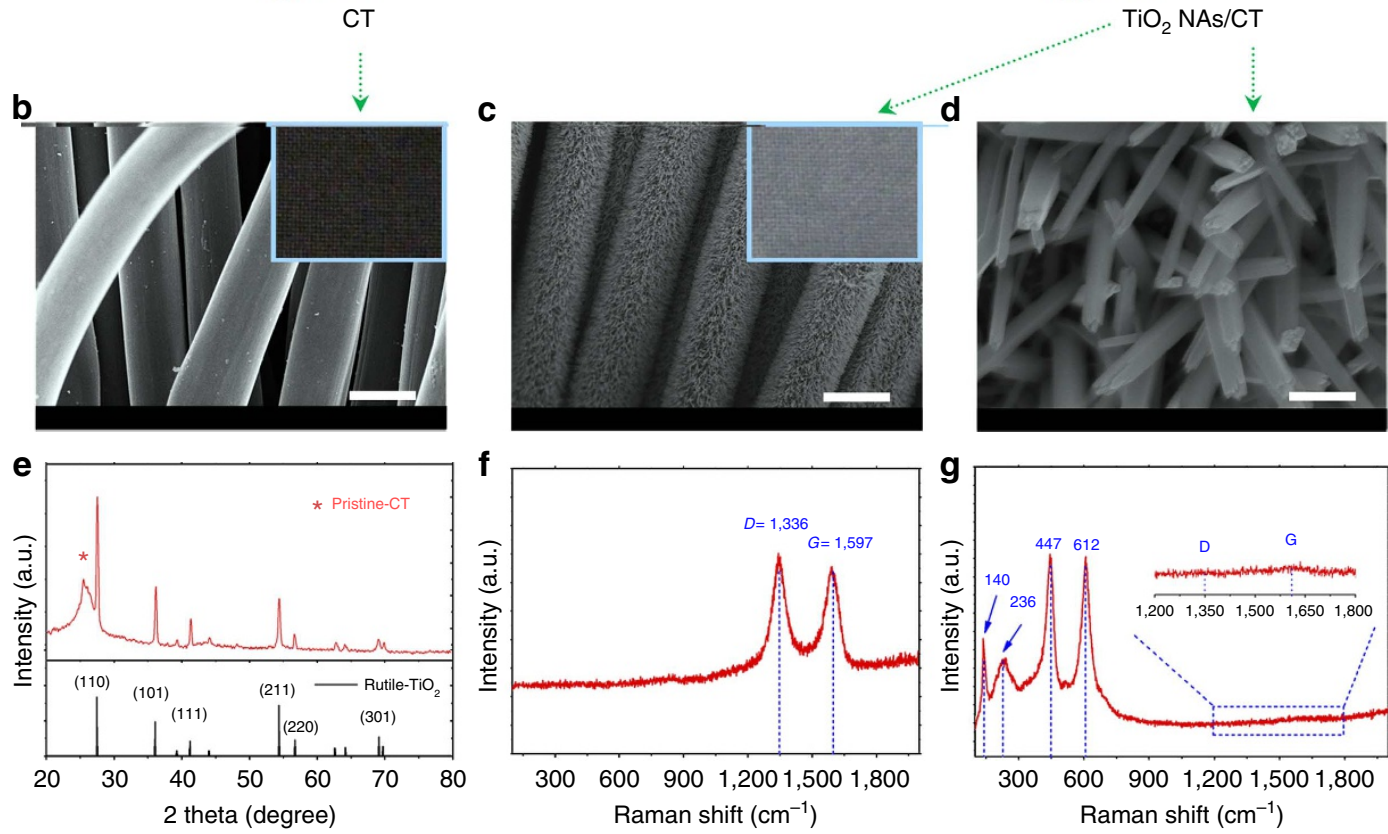

Figure 1 | Scheme for fabrication and structure of the $\mathbf{T i O}_{\mathbf{2}} \mathbf{N A s} / \mathbf{C T}$ cathode. (a) Schematic representations for the design and preparation of the $\mathrm{TiO}_{2} \mathrm{NAs} / \mathrm{CT}$. (b) Scanning electron microscope image and photograph (inset) of pristine-CT (scale bar, $10 \mu \mathrm{m}$ ). (c) SEM image and photograph (inset) of the obtained $\mathrm{TiO}_{2} \mathrm{NAs} / \mathrm{CT}$ cathode (scale bar, $10 \mu \mathrm{m}$ ). (d) Enlarged image of $\mathbf{c}$ with $500-\mathrm{nm}$ scale bars. (e) X-ray diffraction patterns of the obtained $\mathrm{TiO}_{2} \mathrm{NAs} / \mathrm{CT}$ cathode. The asterisk is indexed to carbon textiles. (f) Raman spectra of the pristine-CT cathode. (g) Raman spectra of the $\mathrm{TiO}_{2} \mathrm{NAs} / \mathrm{CT}$ cathode. 
a
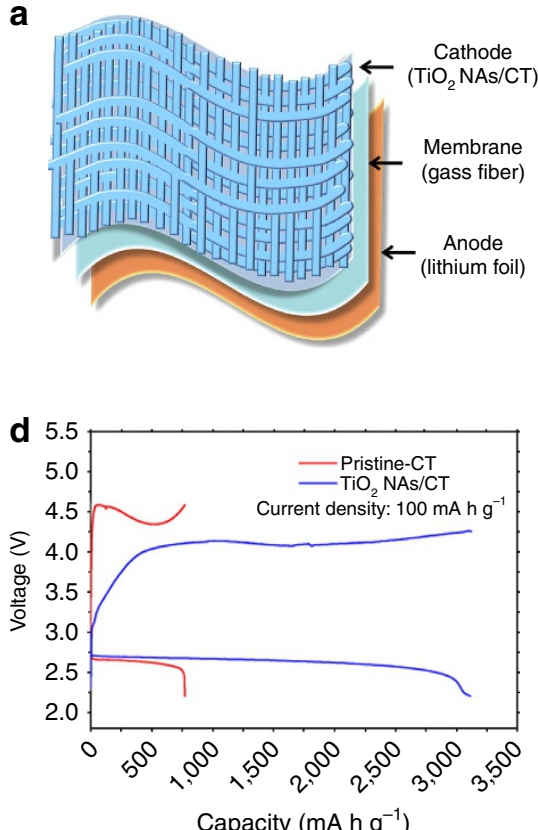

b
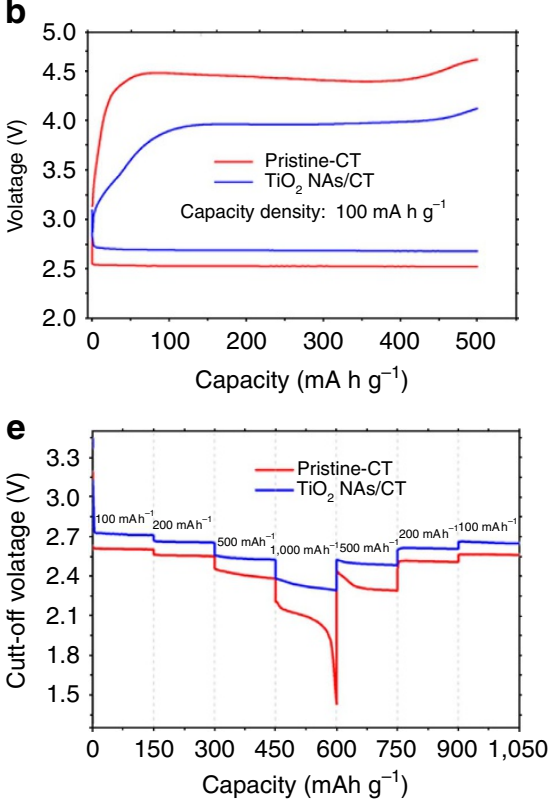

c

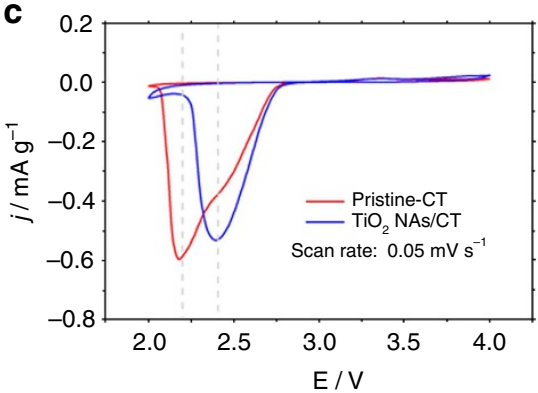

f

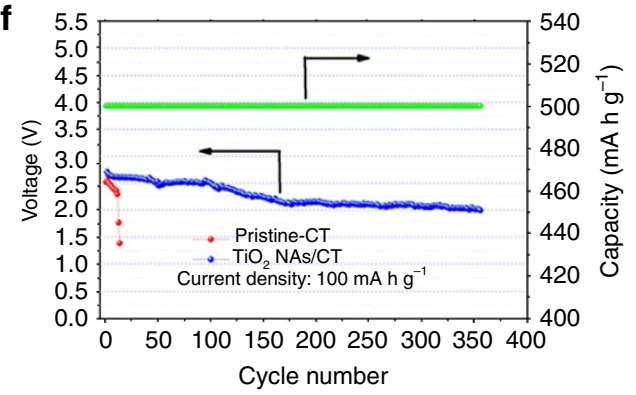

Figure 2 | Cell structure and electrochemical performance. (a) Schematic illustration of the cell assembly composed of $\mathrm{TiO}_{2} \mathrm{NAs} / \mathrm{CT}$ (cathode), glass fibre (separator) and lithium foil (anode). (b) First discharge-charge curves of the $\mathrm{Li}_{-} \mathrm{O}_{2}$ cells with a pristine-CT cathode and a $\mathrm{TiO}_{2} \mathrm{NAs} / \mathrm{CT}$ cathode at a current density of $100 \mathrm{mAg}^{-1}$. The specific capacity was limited to $500 \mathrm{mAhg}^{-1}$. (c) $\mathrm{CVs}_{\mathrm{s}}$ of $\mathrm{Li}_{-} \mathrm{O}_{2}$ cells with the two types of cathodes at a constant scan rate of $0.05 \mathrm{mVs}^{-1}$. (d) Full range test of the $\mathrm{Li}^{-} \mathrm{O}_{2}$ cells with a pristine-CT cathode and a $\mathrm{TiO}_{2} \mathrm{NAs} / \mathrm{CT}$ cathode at a current density of $100 \mathrm{mAg}^{-1}$. These tested cathodes were discharged with the cutoff voltage limited to $2.2 \mathrm{~V}$ and then recharged with the equivalent discharge capacity. (e) The rate capability of the $\mathrm{Li}_{-} \mathrm{O}_{2}$ cells with the two types of cathodes at different current densities. (f) Voltage versus cycle number on the discharge terminal of the $\mathrm{Li}_{-} \mathrm{O}_{2}$ cell with a $\mathrm{TiO}_{2} \mathrm{NAs} / \mathrm{CT}$ cathode.

recoverability by simply rinsing after it loses function. This represents a new strategy to significantly extend the cycle life of $\mathrm{Li}-\mathrm{O}_{2}$ batteries, which is still strongly limited by the instability of the electrolyte.

\section{Results}

Synthesis and analysis of $\mathrm{TiO}_{2}$ NAs grown onto CT. Figure 1a shows the synthesis strategy for producing $\mathrm{TiO}_{2}$ NAs/CT. First, to protect the CT surface effectively, the $\mathrm{TiO}_{2}$ seeds are deposited densely and homogenously onto the carbon fibre of the CT. Then, to accommodate more discharge products in the $\mathrm{Li}-\mathrm{O}_{2}$ cell, the $\mathrm{TiO}_{2} \mathrm{NAs}$ are grown in situ by the $\mathrm{TiO}_{2}$ seeds-directed coordination self-assembly method. Scanning electron microscopic (SEM) images show that the pristine-CT is woven by carbon fibre with diameter of ca. $10 \mu \mathrm{m}$ (Fig. 1b) and that the $\mathrm{TiO}_{2}$ NAs are vertically and homogenously grown onto the skeleton of the CT without the help of any additional binder or solvent (Fig. 1c,d). This ensures the formation of a free-standing structure and a favourable low-resistance pathway for electron transportation. The average diameter of the nanorods is ca. $50 \mathrm{~nm}$ (Supplementary Fig. 1a). The high-resolution transmission electron microscopy image collected at the surface of the $\mathrm{TiO}_{2} \mathrm{NAs}$ reveals lattice fringes of $0.32 \mathrm{~nm}$ in the (110) planes, corresponding to the rutile $\mathrm{TiO}_{2}$ phase (Supplementary Fig. 1b), which were also confirmed by X-ray diffraction (Fig. 1e). Our measured Raman spectra reveal that both the D$\left(1,336 \mathrm{~cm}^{-1}\right)$ and G-band $\left(1,597 \mathrm{~cm}^{-1}\right)$ of the pristine-CT nearly vanish from the $\mathrm{TiO}_{2}$ NAs/CT sample (Fig. 1f,g), demonstrating the effective protection of the CT surface by $\mathrm{TiO}_{2}$ $\mathrm{NAs}^{16}$. The SEM image of $\mathrm{TiO}_{2} \mathrm{NAs} / \mathrm{CT}$ and the corresponding elemental mapping images of $\mathrm{C}, \mathrm{O}$ and $\mathrm{Ti}$ demonstrate the core-shell configuration of $\mathrm{TiO}_{2} \mathrm{NAs} / \mathrm{CT}$ (Supplementary Fig. 2). More importantly, the obtained $\mathrm{TiO}_{2} \mathrm{NAs} / \mathrm{CT}$ cathode is high flexible (Supplementary Fig. 3). Compared with its traditional counterpart, this novel cathode features several tailored properties. First, the $\mathrm{TiO}_{2} \mathrm{NAs} / \mathrm{CT}$ as a free-standing cathode without any polymeric binder can facilitate the high flux of electron transportation throughout the cathode and also avoid the parasitic reaction caused by non-conductive polymeric binder ${ }^{27}$. Second, the $\mathrm{TiO}_{2} \mathrm{NAs} / \mathrm{CT}$ cathode effectively avoids a series of issues caused by the carbon cathode, as described in many other reports, such as the degradation of carbon itself and electrolyte decomposition promoted by carbon material ${ }^{25}$. Finally, the $\mathrm{TiO}_{2}$ NAs/CT is flexible, which is crucial for the assembly of a flexible $\mathrm{Li}-\mathrm{O}_{2}$ battery. All of these advantages benefit the electrochemical performance of the flexible $\mathrm{Li}-\mathrm{O}_{2}$ battery.

Properties of the $\mathrm{TiO}_{2}$ NAs/CT cathode. We constructed a flexible $\mathrm{Li}-\mathrm{O}_{2}$ battery device that contained a flexible pristine-CT or $\mathrm{TiO}_{2} \mathrm{NAs} / \mathrm{CT}$ cathode, a glass fibre separator, and a lithium foil anode (Fig. 2a). Lithium triflate $\left(\mathrm{LiCF}_{3} \mathrm{SO}_{3}\right)$ in tetraethylene glycol dimethyl ether (TEGDME) was employed as the electrolyte because of its reported relatively high stability towards superoxide $\left(\mathrm{O}_{2}^{-}\right)$(refs 28-30). The first discharge and charge voltage of the Li-O $\mathrm{O}_{2}$ battery can be significantly improved with the help of the $\mathrm{TiO}_{2} \mathrm{NAs} / \mathrm{CT}$ cathode. This cathode enhances the round-trip efficiency, which is vital for electrochemical energy storage devices (Fig. 2b). Specifically, compared with the $\mathrm{Li}-\mathrm{O}_{2}$ cell with a pristine-CT cathode, the discharge voltage and charge voltage of that with a $\mathrm{TiO}_{2} \mathrm{NAs} / \mathrm{CT}$ cathode is higher by $160 \mathrm{mV}$ and lower by $495 \mathrm{mV}$, respectively. This result is further supported by the cyclic voltammograms of $\mathrm{Li}-\mathrm{O}_{2}$ cells with either a pristine-CT or $\mathrm{TiO}_{2} \mathrm{NAs} / \mathrm{CT}$ cathode (Fig. 2c). The cell with a $\mathrm{TiO}_{2} \mathrm{NAs} / \mathrm{CT}$ cathode has a higher peak potential compared with the cell with a pristine-CT cathode, suggesting that $\mathrm{TiO}_{2}$ NAs/CT exhibits better ORR catalytic activity. However, the peak current of the 
a

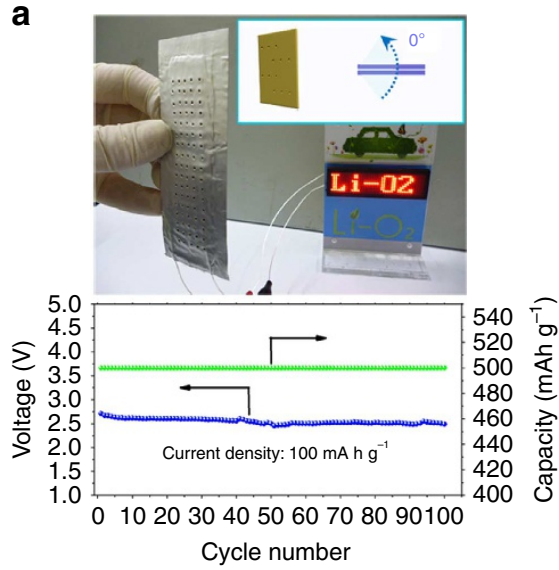

d

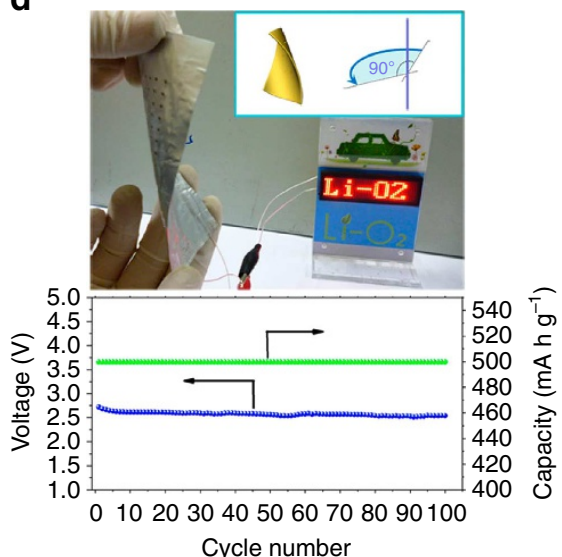

b

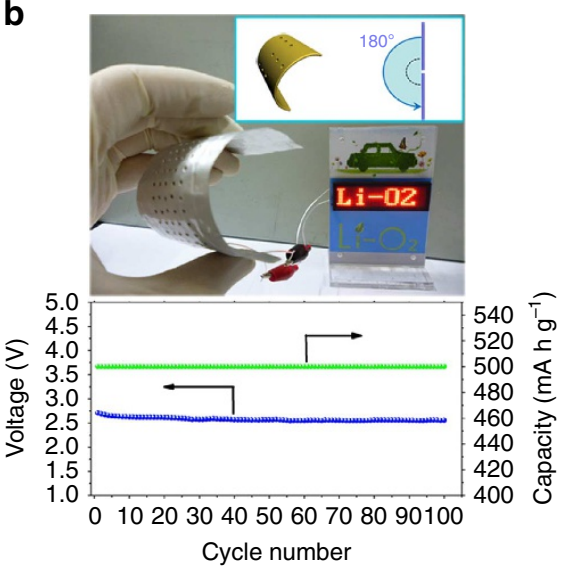

e

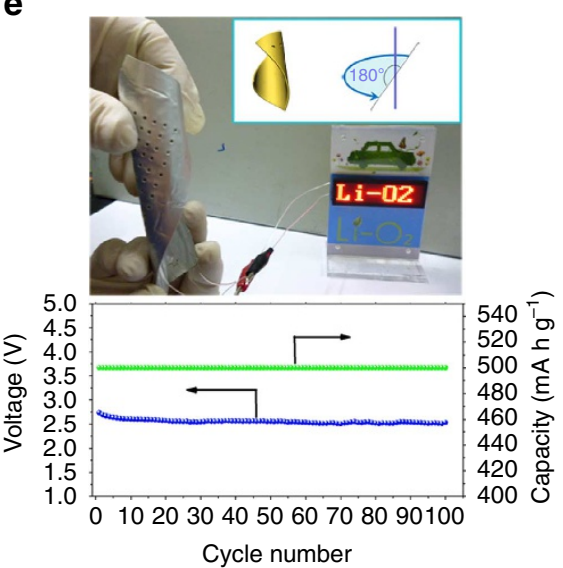

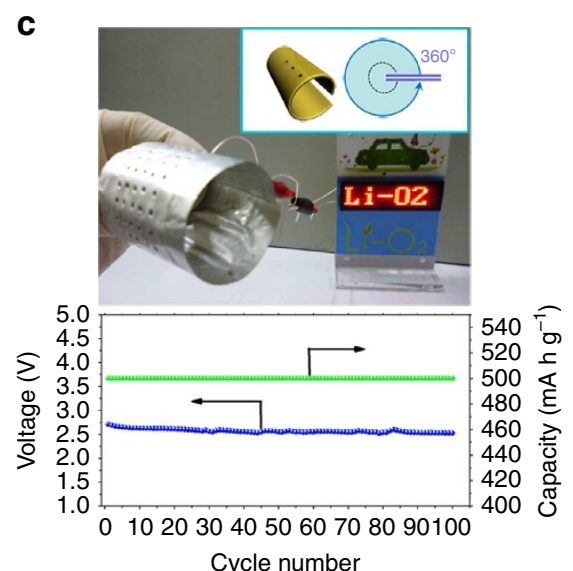

f

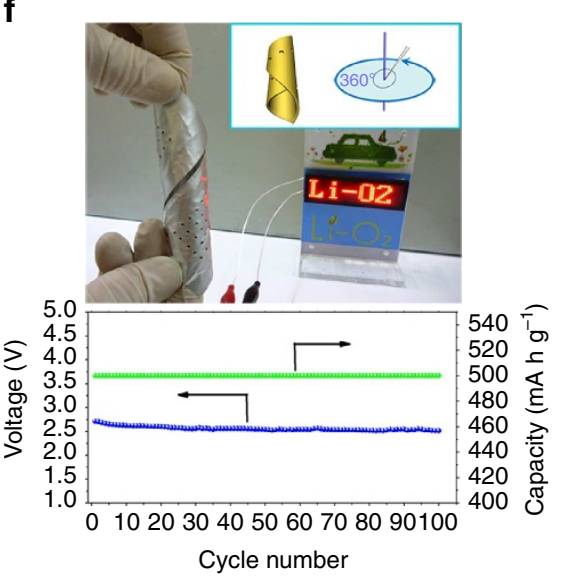

Figure 3 | The bending and twisting properties of the $\mathbf{L i}-\mathbf{O}_{\mathbf{2}}$ battery device. (a-c) The bending properties with the device bent to $0^{\circ}, 180^{\circ}$ and $360^{\circ}$, respectively. (d-f) The twisting properties with the device twisted to $90^{\circ}, 180^{\circ}$ and $360^{\circ}$, respectively. The corresponding variation of terminal discharge voltage versus cycle number of the $\mathrm{Li}_{-} \mathrm{O}_{2}$ cells with $\mathrm{TiO}_{2} \mathrm{NAs} / \mathrm{CT}$ cathode is shown in each panel.

$\mathrm{TiO}_{2}$ NAs/CT cathode is lower than that of the pristine-CT cathode, which might be due to the lower conductivity of $\mathrm{TiO}_{2}$ compared with that of pristine-CT. In addition, the $\mathrm{Li}-\mathrm{O}_{2}$ cell with a $\mathrm{TiO}_{2} \mathrm{NAs} / \mathrm{CT}$ cathode exhibits a much higher discharge capacity than that with a pristine-CT cathode $\left(3,000 \mathrm{mAhg}^{-1}\right.$ versus $770 \mathrm{mAh} \mathrm{g}^{-1}$ ) (Fig. 2d). Furthermore, to exclude possible electrochemical contributions from the intercalation of lithium ions $\left(\mathrm{Li}^{+}\right)$into pristine-CT or $\mathrm{TiO}_{2} \mathrm{NAs} / \mathrm{CT}$ materials, the initial discharge curves of $\mathrm{Li}-\mathrm{O}_{2}$ cells with pristine-CT and $\mathrm{TiO}_{2} \mathrm{NAs} /$ $\mathrm{CT}$ cathodes under an argon (Ar) atmosphere were also obtained for comparison (Supplementary Fig. 4). Clearly, the background discharge capacity is negligible within the voltage range, which suggests that the above obtained enhanced discharge capacities of the $\mathrm{Li}-\mathrm{O}_{2}$ cells are derived from the oxygen reduction. Our rate performance investigations show that the discharge voltage plateau of the $\mathrm{TiO}_{2} \mathrm{NAs} / \mathrm{CT}$ cathode is higher than that of pristine$\mathrm{CT}$ at each current density (Fig. 2e, consistent with Fig. 2b). Furthermore, the cell with the $\mathrm{TiO}_{2} \mathrm{NAs} / \mathrm{CT}$ cathode can discharge/charge for $>356$ cycles with a discharge terminal voltage $>2.0 \mathrm{~V}$, which is ca. 30 times longer than the cell with the pristine-CT cathode, that is, 12 cycles (Fig. 2f, Supplementary Fig. 5). All of these improvements, including the cyclic stability with the capacity limit of 1,000 $\mathrm{mAh}^{-1}$ (Supplementary Fig. 6), further confirm the advantages of the $\mathrm{TiO}_{2} \mathrm{NAs} / \mathrm{CT}$ cathode, which may be attributed to the synergistic effect of the high catalytic activity and the tailored free-standing structure of the $\mathrm{TiO}_{2} \mathrm{NAs} / \mathrm{CT}$ cathode. $\mathrm{TiO}_{2} \mathrm{NAs}$ provides enough void volume for the deposition of discharge products, therefore, resulting in a much enhanced discharge capacity. In general, although charge transfer is the rate-determining process at low current densities, when the current density increases, the mass transfer of lithium ions and oxygen can become the rate-determining process. A uniform oxygen and lithium-ion distribution inside the $\mathrm{TiO}_{2}$ NAs/CT cathode is required to improve the rate capability, especially, at very high current densities ${ }^{31}$. Furthermore, the morphology and crystallinity of the discharge product in $\mathrm{TiO}_{2}$ NAs/CT cathode also contributes positively to the high specific capacity, rate capability and cycling stability of $\mathrm{Li}-\mathrm{O}_{2}$ cells (vide infra).

Bending and twisting properties. To demonstrate its potential application in flexible electronics, the as-fabricated flexible $\mathrm{Li}-\mathrm{O}_{2}$ battery with a $\mathrm{TiO}_{2} \mathrm{NAs} / \mathrm{CT}$ cathode was used to power a commercial red light-emitting diode display screen (Fig. 3). The terminal discharge voltage of the devices after being bent to $180^{\circ}$ (Fig. 3b) and $360^{\circ}$ (Fig. 3c) were 2.55 and $2.52 \mathrm{~V}$ after 100 cycles, respectively, which was even slightly better than that without bending ( $2.49 \mathrm{~V}$, Fig. 3a). Even under more stringent conditions, the terminal discharge voltages after 100 cycles were $2.54,2.51$ and $2.52 \mathrm{~V}$ at torsion angles of $90^{\circ}$ (Fig. 3d), $180^{\circ}$ (Fig. 3e) and $360^{\circ}$ (Fig. 3f), respectively. Furthermore, it can be seen that the terminal discharge-charge voltage versus cycle number of the device remained almost constant even after 100 cycles, revealing that the electrochemical stability of the fabricated flexible $\mathrm{Li}-\mathrm{O}_{2}$ battery is hardly affected by external bending or twisting strains (Supplementary Fig. 7). In addition, the $\mathrm{TiO}_{2} \mathrm{NAs} / \mathrm{CT}$ cathode also possesses good mechanical integrity even after twisting for 1,000 cycles (Supplementary Fig. 8). These results collectively 
a

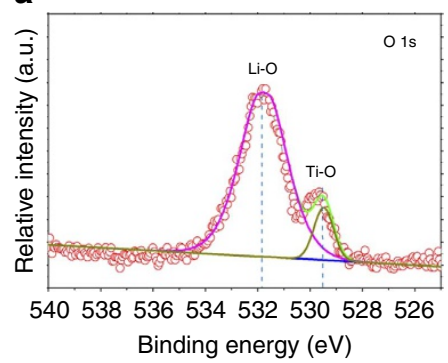

d

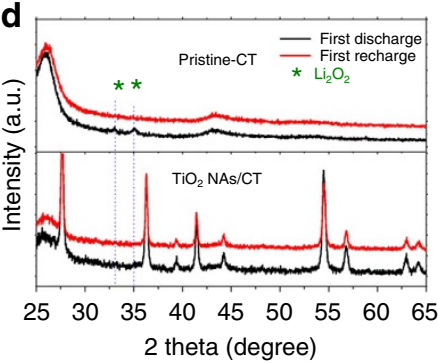

b
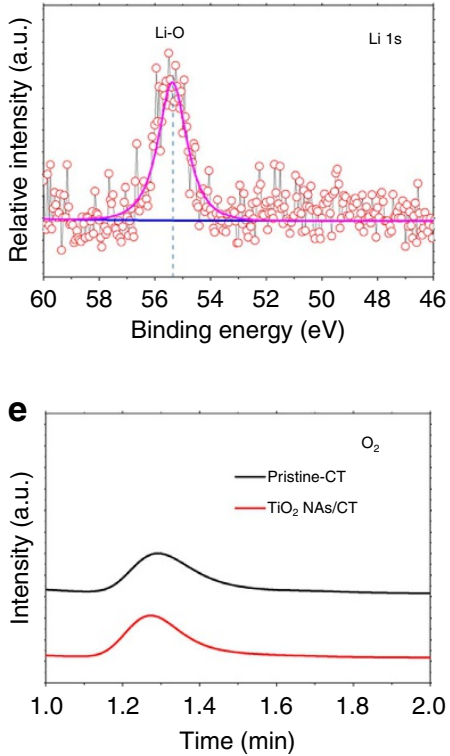

C

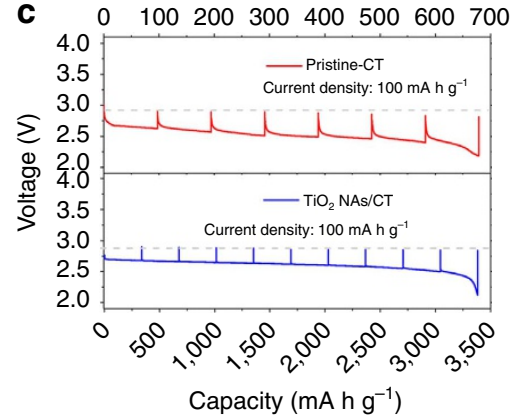

f

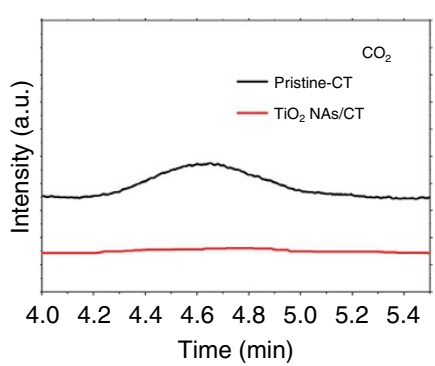

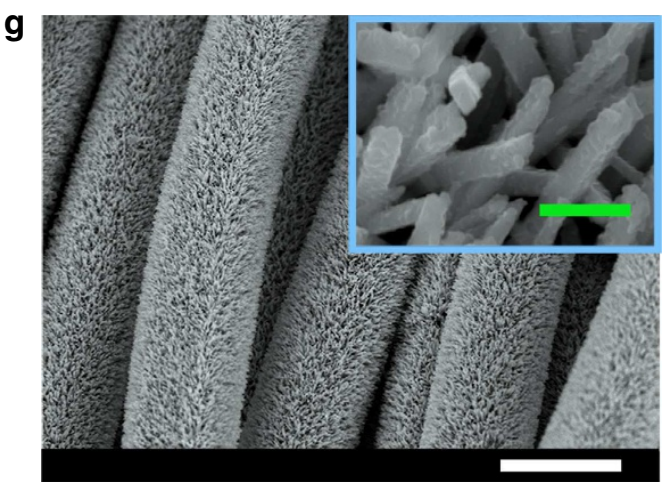

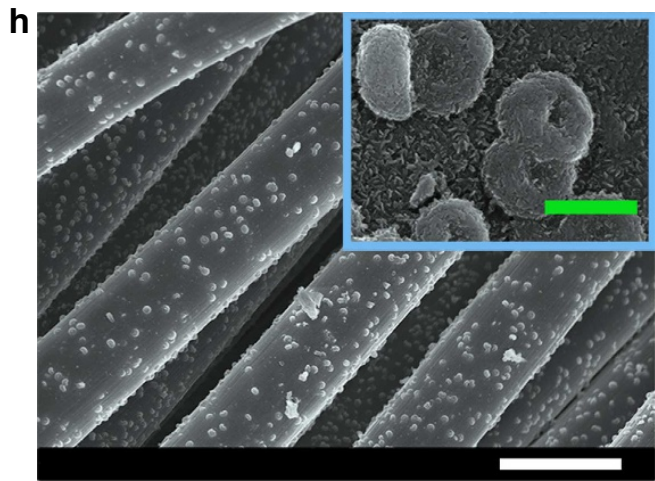

Figure 4 | Characterization of discharge products. (a) O1s X-ray photoelectron spectroscopy (XPS) spectra of the discharged TiO $\mathrm{NAs}_{2} \mathrm{CT}$ cathode. (b) Lils XPS spectra of the discharged $\mathrm{TiO}_{2} \mathrm{NAs} / \mathrm{CT}$ cathode. (c) GITT discharge voltage profile obtained from the Li-O $\mathrm{O}_{2}$ cell with a pristine-CT cathode (red) and (a) $\mathrm{TiO}_{2} \mathrm{NAs} / \mathrm{CT}$ cathode (blue) at first discharge with a current density of $100 \mathrm{mAg}^{-1}$. Both curves show an equilibrium potential of the Li- $\mathrm{O}_{2}$ cell of near $2.9 \mathrm{~V}$ regardless of the state of discharge, which is in accordance with the formation potential of $\mathrm{Li}_{2} \mathrm{O}_{2}$. (d) Corresponding $\mathrm{X}$-ray diffraction patterns of the two types of discharged cathodes. (e) Gas chromatography (GC) signals of $\mathrm{O}_{2}$ released after charging the Li-O $\mathrm{O}_{2}$ cells with a pristine-CT cathode (black) and a $\mathrm{TiO}_{2} \mathrm{NAs} / \mathrm{CT}$ cathode (red), which were obtained with a thermal conductivity detector (TCD). (f) $\mathrm{GC}$ signal of $\mathrm{CO}_{2}$ released. (g) SEM images of the discharged $\mathrm{TiO}_{2} \mathrm{NAs} / \mathrm{CT}$ cathode with a current density of $100 \mathrm{mAg}^{-1}$ (white scale bar, $10 \mu \mathrm{m}$, green scale bars: $500 \mathrm{~nm}$ ). (h) SEM images of the discharged pristine-CT cathode with a current density of $100 \mathrm{mAg}^{-1}$ (white scale bar, $10 \mu \mathrm{m}$, green scale bar, $500 \mathrm{~nm}$ ).

demonstrate the excellent flexibility of this newly constructed flexible $\mathrm{Li}-\mathrm{O}_{2}$ device, and no structural failure was observed after various bending and twisting tests.

Analysis of the discharge products. The discharge products of the $\mathrm{Li}-\mathrm{O}_{2}$ battery with a $\mathrm{TiO}_{2} \mathrm{NAs} / \mathrm{CT}$ cathode were investigated using X-ray photoelectron spectroscopy (Fig. 4a,b) The peaks positioned at 55.5 and $531.9 \mathrm{eV}$ can be assigned to the $\mathrm{Li}-\mathrm{O}$ bond of lithium peroxides $\left(\mathrm{Li}_{2} \mathrm{O}_{2}\right)^{32}$, which is supported by the equilibrium potential of the $\mathrm{Li}-\mathrm{O}_{2}$ battery of ca. $2.9 \mathrm{~V}$ (theoretical formation potential of $\mathrm{Li}_{2} \mathrm{O}_{2}$ ) obtained using the galvanostatic intermittent titration technique (Fig. 4c) ${ }^{33}$. However, when compared with X-ray diffraction patterns of the discharged pristine-CT cathode (Fig. $4 \mathrm{~d}$ ), the characteristic peaks of $\mathrm{Li}_{2} \mathrm{O}_{2}$ were not observed in the $\mathrm{TiO}_{2} \mathrm{NAs} / \mathrm{CT}$ cathode, demonstrating the amorphous nature of $\mathrm{Li}_{2} \mathrm{O}_{2}$ formed in the $\mathrm{TiO}_{2} \mathrm{NAs} / \mathrm{CT}$ cathode. It has been reported that $\mathrm{TiO}_{2}$ NAs may possess a suitable oxygen binding energy and high affinity for oxygen coverage. This would lead to stronger oxygen adsorption on the $\mathrm{TiO}_{2}$ NAs surface than that of the CT, which may facilitate the formation of amorphous $\mathrm{Li}_{2} \mathrm{O}_{2}$ (ref. 34). Furthermore, in sharp contrast to the conventional toroidal morphology of the discharge product obtained on the pristine-CT cathode (Fig. 4h) ${ }^{35,36}$, amorphous $\mathrm{Li}_{2} \mathrm{O}_{2}$ films are homogenously coated onto $\mathrm{TiO}_{2} \mathrm{NAs}$ (Fig. $4 \mathrm{~g}$ ). This amorphous $\mathrm{Li}_{2} \mathrm{O}_{2}$ film may contain many defects (for example, lithium vacancies) that provide channels for electron and especially ion conduction, thus enhancing the electrode kinetics during the charge process towards a reduced charge overpotential (Fig. 2b) ${ }^{37,38}$. In addition, it should be noted that recent theoretical calculations have demonstrated that polycrystalline grain boundaries of $\mathrm{Li}_{2} \mathrm{O}_{2}$ can also significantly influence the charging overpotential of a $\mathrm{Li}-\mathrm{O}_{2}$ battery ${ }^{39}$. Therefore, because $\mathrm{Li}-\mathrm{O}_{2}$ batteries are still relatively new, additional research efforts including in situ transmission electron microscopy (TEM) observations should be devoted to clarifying the effect of the crystallinity of $\mathrm{Li}_{2} \mathrm{O}_{2}$ on the charging process of $\mathrm{Li}-\mathrm{O}_{2}$ batteries. Although the toroidal products decorated on the CT are mostly decomposed after subsequent recharging processes (Supplementary Fig. 9a), the surface of CT becomes rough and many holes appear on the pristine-CT 
a

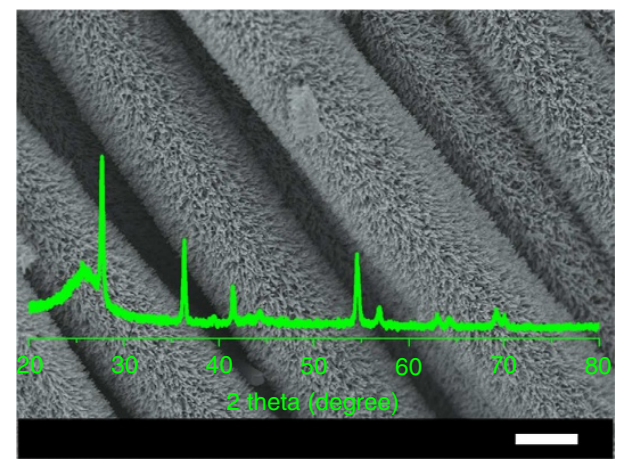

c

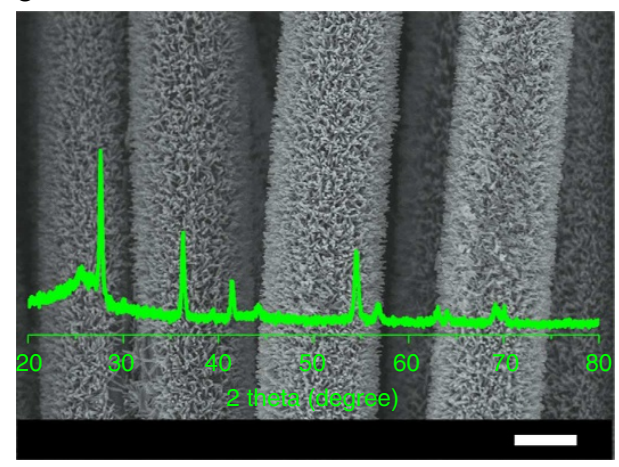

e

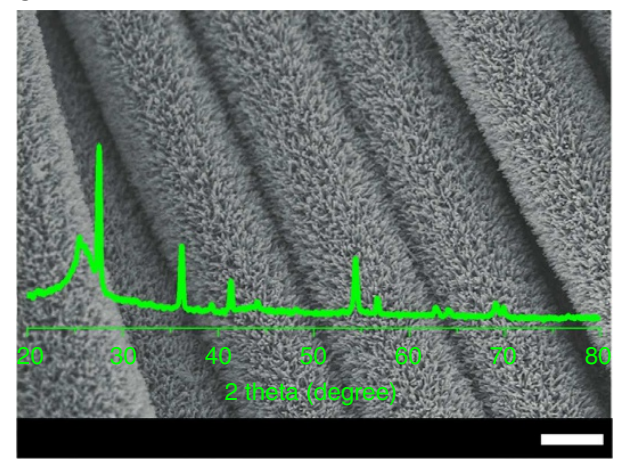

b

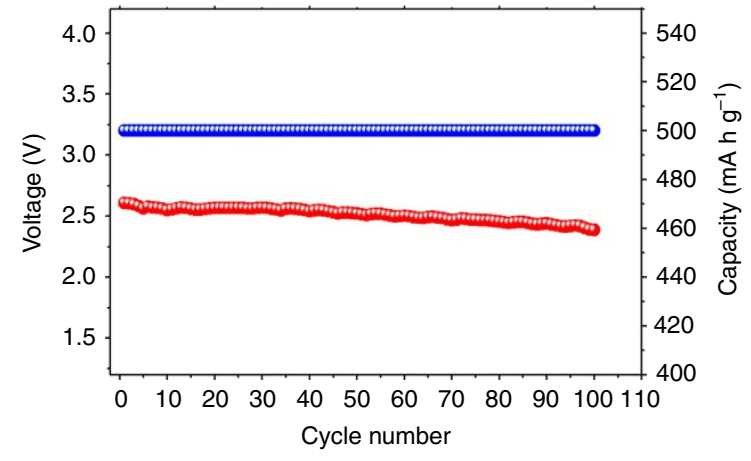

d

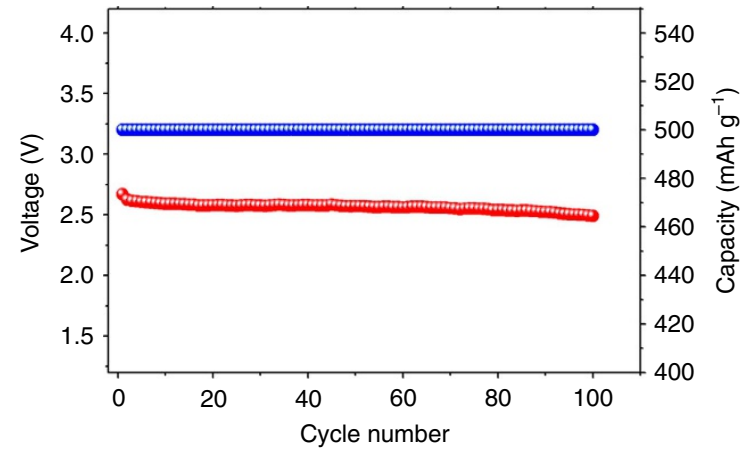

f

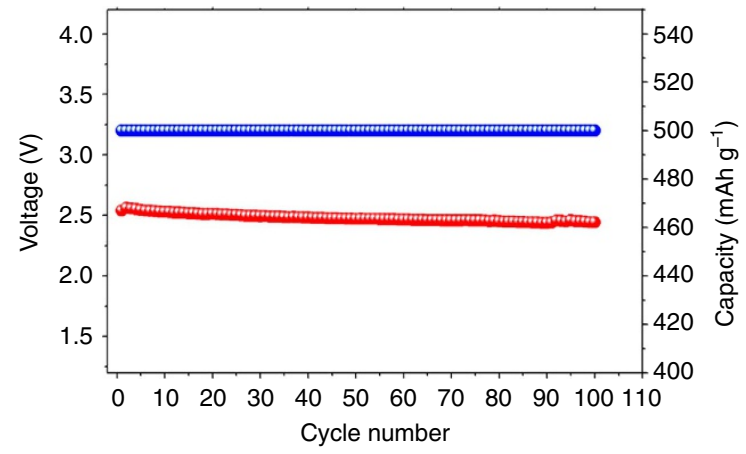

Figure 5 | Recoverable performance. (a) SEM images of the pristine $\mathrm{TiO}_{2} \mathrm{NAs} / \mathrm{CT}$ cathode. (scale bar, $5 \mu \mathrm{m}$ ). The inset in a is the corresponding X-ray diffraction pattern. (b) The variation of the terminal discharge voltage of the pristine $\mathrm{TiO}_{2} \mathrm{NAs} / \mathrm{CT}$ cathode with a current density of $100 \mathrm{mAg}$. 1 . (c) SEM images of the first-recovered $\mathrm{TiO}_{2} \mathrm{NAs} / \mathrm{CT}$ cathode (scale bar, $5 \mu \mathrm{m}$ ). The inset in $\mathbf{c}$ is the corresponding X-ray diffraction pattern. (d) The variation of the terminal discharge voltage of the first-recovered $\mathrm{TiO}_{2} \mathrm{NAs} / \mathrm{CT}$ cathode with a current density of $100 \mathrm{mAg}^{-1}$. (e) SEM images of the 10th-recovered $\mathrm{TiO}_{2} \mathrm{NAs} / \mathrm{CT}$ cathode (scale bar, $5 \mu \mathrm{m}$ ). The inset in $\mathbf{e}$ is the corresponding X-ray diffraction pattern. (f) The variation of the terminal discharge voltage of the tenth recovered $\mathrm{TiO}_{2} \mathrm{NAs} / \mathrm{CT}$ cathode with a current density of $100 \mathrm{mAg}^{-1}$.

cathode (Supplementary Fig. 9b) compared with the original one (Fig. 1b). This indicates the existence of serious parasitic reactions between the CT and $\mathrm{Li}_{2} \mathrm{O}_{2}$ and/or nascent $\mathrm{O}_{2}$ (ref. 31), which was confirmed by the large amount of $\mathrm{CO}_{2}$ gas generated $(2.12 \mu \mathrm{l})$ during the charging process (Supplementary Figs 10 and 11, and Supplementary Table 1). In sharp contrast, for the $\mathrm{TiO}_{2} \mathrm{NAs} / \mathrm{CT}$ cathode, the $\mathrm{TiO}_{2}$ NAs recovered to its initial state, with the surface becoming smooth again (Supplementary Fig. 9d), which was confirmed by a trace amount of $\mathrm{CO}_{2}$ gas generated $(0.04 \mu \mathrm{l}$; Fig. 4f, Supplementary Fig. 12, Supplementary Table 1), wherein the reaction mechanism during discharge/charge processes are proposed to be investigated by in situ differential electrochemical mass spectroscopy in the future. Unexpectedly, the smooth surface of the $\mathrm{TiO}_{2}$ NAs/CT cathode was retained even after multiple cycles (10th, 50th and 100th cycle) of the $\mathrm{Li}-\mathrm{O}_{2}$ cell, which demonstrates the good rechargeability of the $\mathrm{TiO}_{2} \mathrm{NAs} / \mathrm{CT}$ cathode and the stability of $\mathrm{TiO}_{2}$ NAs (Supplementary Figs 13 and 14).

\section{Discussion}

Electrolyte decomposition, which is due to the continuous accumulation of the side products such as $\mathrm{Li}_{2} \mathrm{CO}_{3}$ and $\mathrm{Li}$ alkyl carbonates on the cathode surface (Supplementary Fig. 15), still inevitably resulted in premature death of the $\mathrm{Li}-\mathrm{O}_{2}$ battery. Currently, these cathodes can only be abandoned due to serious damage of the structure and chemical composition. Inspired by the rather high structural and chemical stability of the $\mathrm{TiO}_{2}$ NAs/CT cathode, we simply rinsed the $\mathrm{TiO}_{2}$ NAs/CT cathode (even after 100 discharge/charge cycles) with $2 \mathrm{M} \mathrm{HCl}$ to remove the residual carbonates. Interestingly, the free-standing structure and chemical composition of the disabled $\mathrm{TiO}_{2}$ NAs/CT 
cathode were restored after washing, demonstrating the excellent recoverability of the $\mathrm{TiO}_{2} \mathrm{NAs} / \mathrm{CT}$ cathode (Fig. 5c). Unexpectedly, the rebuilt cell exhibits almost the same voltage profiles (Fig. 5d) as the fresh one (Fig. 5b), even after 100 cycles. To further demonstrate its superior recoverability, the 3rd-, 5th-, and 10th-recovered $\mathrm{TiO}_{2} \mathrm{NAs} / \mathrm{CT}$ cathode was also investigated, as shown in Fig. 5e,f and Supplementary Fig. 16. Although the $\mathrm{TiO}_{2}$ NAs/CT cathode was recovered 10 times, there was no obvious degradation of the structure or electrochemical performance of the $\mathrm{TiO}_{2} \mathrm{NAs} / \mathrm{CT}$ cathode (Fig. $5 e, \mathrm{f}$ ).

In conclusion, we have shown that a highly flexible $\mathrm{Li}-\mathrm{O}_{2}$ battery can be constructed by employing a free-standing and recoverable $\mathrm{TiO}_{2} \quad \mathrm{NAs} / \mathrm{CT}$ cathode. Superior electrochemical performances in terms of round-trip efficiency, rate capability and cycling stability, even under harsh bending and twisting conditions, have been achieved. These characteristics may be attributable to the tailored properties of the $\mathrm{TiO}_{2}$ NAs/CT cathode, which include high mechanical and chemical stability as well as high catalytic activity. Furthermore, the excellent recoverability of the $\mathrm{TiO}_{2}$ NAs/CT cathode can significantly extend the cycle life (at least 1,000 cycles) and decrease the whole-life cycle cost of $\mathrm{Li}-\mathrm{O}_{2}$ batteries. However, if the same benefits could be extended to a more highly efficient cathode (Supplementary Figs 17-19) and coupled with a next-generation stable electrolyte, an advanced flexible $\mathrm{Li}-\mathrm{O}_{2}$ battery could be expected to dominate the upcoming field of flexible electronics. Hence, the results obtained here will hopefully encourage further studies on flexible $\mathrm{Li}-\mathrm{O}_{2}$ cells, although numerous challenges precluding their use in practical devices remain.

\section{Methods \\ Chemicals and materials. Titanium $n$-butoxide $\left(\mathrm{C}_{16} \mathrm{H}_{36} \mathrm{O}_{4} \mathrm{Ti}\right)$, isopropanol $\left(\mathrm{C}_{3} \mathrm{H}_{8} \mathrm{O}\right)$, ethanol $(\mathrm{EtOH})$, hydrochloric acid $(\mathrm{HCl})$ and acetone $\left(\mathrm{C}_{3} \mathrm{H}_{6} \mathrm{O}\right)$ were purchased from Sinopharm Chemical Reagent Co. Ltd., Shanghai, China. Tetraethylene glycol dimethyl ether, lithium triflate $\left(\mathrm{LiCF}_{3} \mathrm{SO}_{3}\right)$ and sodium tetrachloropalladate $\left(\mathrm{Na}_{2} \mathrm{PdCl}_{4}\right)$ were purchased from Aladdin Reagent. Carbon textiles were purchased from Torray.}

$\mathrm{TiO}_{2} \mathbf{N A s} / \mathbf{C T}$ cathode preparation. The $\mathrm{TiO}_{2} \mathrm{NAs} / \mathrm{CT}$ cathode was synthesized using a seed-assisted method. The CT were ultrasonically cleaned with $\mathrm{C}_{3} \mathrm{H}_{6} \mathrm{O}$ and distilled water several times and then dried at $60^{\circ} \mathrm{C}$ in a vacuum oven. The clean CT were immersed in a $0.075 \mathrm{M}$ titanium $n$-butoxide isopropanol solution, rinsed with ethanol, and then dried in an air oven at $60^{\circ} \mathrm{C}$ three times. The dried CT were subsequently heated in air at $500^{\circ} \mathrm{C}$ for $1 \mathrm{~h}$, forming $\mathrm{TiO}_{2}$ nanoparticles coated on the CT. Next, $0.66 \mathrm{ml}$ titanium $n$-butoxide isopropanol was added into a solution of $15 \mathrm{ml}$ concentrated hydrochloric acid and $15 \mathrm{ml}$ deionized water. The mixture was stirred for $>6 \mathrm{~h}$ and a clear solution was obtained. This clear solution together with the CT-coated $\mathrm{TiO}_{2}$ nanoparticles were transferred to a Teflon-lined stainless steel autoclave ( $50 \mathrm{ml}$ volume) and heated in an oven at $150^{\circ} \mathrm{C}$ for $12 \mathrm{~h}$. When the oven cooled down, the CT were removed from the autoclave and rinsed with deionized water several times and dried in an air oven at $60^{\circ} \mathrm{C}$. Finally, the sample was annealed in air at $550^{\circ} \mathrm{C}$ for $2 \mathrm{~h}$.

Fabrication of Pd decorated $\mathrm{TiO}_{\mathbf{2}} \mathbf{N A s} / \mathbf{C T}$ cathode. The obtained $\mathrm{TiO}_{2} \mathrm{NAs} / \mathrm{CT}$ cathode was directly immersed into $\mathrm{Na}_{2} \mathrm{PdC}_{14}$ aqueous solution $(5 \mathrm{mM})$ and exposed to light for $30 \mathrm{~min}$. The cathode was finally rinsed with deionized water several times and dried in an air oven at $60^{\circ} \mathrm{C}$.

Characterization. The morphologies and structures of the materials were characterized using various physiochemical techniques, including X-ray diffraction, field emission scanning electron microscopy, TEM, and Raman spectral analysis. The discharge and recharge products were characterized using X-ray photoelectron spectroscopy, X-ray diffraction, gas chromatography and mass spectrometry.

Assembling of the flexible $\mathrm{Li}-\mathrm{O}_{\mathbf{2}}$ battery device. The flexible $\mathrm{Li}-\mathrm{O}_{2}$ battery device was assembled in an argon-filled glove box using a commercial lithium belt anode, a glass fibre separator, an oxygen cathode and a $1-\mathrm{M} \mathrm{LiCF}_{3} \mathrm{SO}_{3}$ in TEGDME electrolyte. The as-fabricated $\mathrm{TiO}_{2} \mathrm{NAs} / \mathrm{CT}(6 \times 2 \mathrm{~cm})$ was directly used as the air cathode without any polymeric binder.
Recovery of the $\mathrm{TiO}_{\mathbf{2}} \mathbf{N A s} / \mathbf{C T}$ cathode. $\mathrm{TiO}_{2} \mathrm{NAs} / \mathrm{CT}$ cathode was disassembled from the $\mathrm{Li}-\mathrm{O}_{2}$ battery device after multiple cycles, rinsed with $2 \mathrm{M} \mathrm{HCl}$, washed with distilled water several times and subsequently dried in air oven at $60^{\circ} \mathrm{C}$ for utilization.

Instrumentation. SEM was performed on a Hitachi S-4800 field emission scanning electron microscope operating with an acceleration voltage of $10 \mathrm{kV}$. Samples for SEM were prepared by directly placing the electrode sample onto an SEM brass stub. The X-ray diffraction measurements were performed on a Bruker D8 Focus X-ray diffractometer using $\mathrm{Cu} K \alpha$ radiation. TEM was performed using an FEI Tecnai G2 S-Twin transmission electron microscope with a field emission gun operating at $200 \mathrm{kV}$. The X-ray photoelectron spectroscopy measurements were performed on an ESCA-LAB 250 photoelectron spectrometer Electrochemical impedance spectroscopy and CV measurements were performed on a BioLogic VMP3 electrochemical workstation. The $\mathrm{Li}-\mathrm{O}_{2}$ battery device measurements were cycled on a LAND CT2001A multichannel battery testing system. For the gas chromatography (Techcomp GC-7900) measurements, a glass chamber containing the $\mathrm{Li}-\mathrm{O}_{2}$ battery following discharging was flooded with $\mathrm{Ar}$. The gas was then collected for analyses after the battery was charged. $\mathrm{O}_{2}$ and $\mathrm{CO}_{2}$ were analysed with a thermal conductivity detector using Ar as the carrier gas (detection limit: 10 p.p.m.). Mass analysis of the generated gases was performed using an OmniStar GSD 320 system (Pfeiffer Vacuum) mass spectrometry, wherein argon gas was chosen as the carrier gas. A xenon light source (PLS-SXE300C) was employed for the photochemical deposition of Pd nanoparticles.

\section{References}

1. De Volder, M. F., Tawfick, S. H., Baughman, R. H. \& Hart, A. J. Carbon nanotubes: present and future commercial applications. Science 339, 535-539 (2013).

2. Hu, L. \& Cui, Y. Energy and environmental nanotechnology in conductive paper and textiles. Energy Environ. Sci. 5, 6423-6435 (2012).

3. Rogers, J. A., Someya, T. \& Huang, Y. Materials and mechanics for stretchable electronics. Science 327, 1603-1607 (2010).

4. Liu, Z., Xu, J., Chen, D. \& Shen, G.-Z. Flexible electronics based on inorganic nanowires. Chem. Soc. Rev. 44, 161-192 (2015).

5. Li, L., Wu, Z., Yuan, S. \& Zhang, X.-B. Advances and challenges for flexible energy storage and conversion devices and systems. Energy Environ. Sci. 7, 2101-2122 (2014).

6. Li, N., Chen, Z. P., Ren, W. C., Li, F. \& Cheng, H.-M. Flexible graphene-based lithium ion batteries with ultrafast charge and discharge rates. Proc. Natl Acad. Sci. USA 109, 17360-17365 (2012).

7. Liu, B. et al. Hierarchical three-dimensional $\mathrm{ZnCo}_{2} \mathrm{O}_{4}$ nanowire arrays/carbon cloth anodes for a novel class of high-performance flexible lithium-ion batteries. Nano Lett. 12, 3005-3011 (2012).

8. $\mathrm{Xu}$, S. et al. Stretchable batteries with self-similar serpentine interconnects and integrated wireless recharging systems. Nat. Commun. 4, 1543 (2013).

9. Kil, E.-H. et al. Imprintable, bendable and shape-conformable polymer electrolytes for versatile-shaped lithium-ion batteries. Adv. Mater. 25, 1395-1400 (2013).

10. Cheng, Q. et al. Folding paper-based lithium-ion batteries for higher areal energy densities. Nano Lett. 13, 4969-4974 (2013).

11. Lang, X., Hirata, A., Fujita, T. \& Chen, M. Nanoporous metal/oxide hybrid electrodes for electrochemical supercapacitors. Nat. Nanotechnol 6, 232-236 (2011).

12. Li, H. et al. Novel planar-structure electrochemical devices for highly flexible semitransparent power generation/storage sources. Nano Lett. 13, 1271-1277 (2013).

13. Gao, W. et al. Direct laser writing of micro-supercapacitors on hydrated graphite oxide films. Nat. Nanotechnol. 6, 496-500 (2011).

14. Lee, J. A. et al. Ultrafast charge and discharge biscrolled yarn supercapacitors for textiles and microdevices. Nat. Commun. 4, 1970 (2013).

15. Pech, D. et al. Ultrahigh-power micrometre-sized supercapacitors based on onion-like carbon. Nat. Nanotechnol 5, 651-654 (2010).

16. Lipomi, D. J., Tee, B. C., Vosgueritchian, M. \& Bao, Z. Stretchable organic solar cells. Adv. Mater. 23, 1771-1775 (2011).

17. Liu, Z., Li, J. \& Yan, F. Package-free flexible organic solar cells with graphene top electrodes. Adv. Mater. 25, 4296-4301 (2013).

18. Kaltenbrunner, M. et al. Ultrathin and lightweight organic solar cells with high flexibility. Nat. Commun. 3, 770 (2012).

19. Lee, Y. H. et al. Wearable textile battery rechargeable by solar energy. Nano Lett. 13, 5753-5761 (2013).

20. Peng, Z., Freunberger, S. A., Chen, Y. \& Bruce, P. G. A reversible and higher-rate $\mathrm{Li}_{-} \mathrm{O}_{2}$ battery. Science 337, 563-566 (2012).

21. McCloskey, B. D. et al. On the efficacy of electrocatalysis in nonaqueous $\mathrm{Li}^{-} \mathrm{O}_{2}$ batteries. J. Am. Chem. Soc. 133, 18038-18041 (2011).

22. Jung, H. G., Hassoun, J., Park, J. B., Sun, Y. K. \& Scrosati, B. An improved high-performance lithium-air battery. Nat. Chem. 4, 579-585 (2012). 
23. Xiao, J. et al. Hierarchically porous graphene as a lithium-air battery electrode. Nano Lett. 11, 5071-5078 (2011).

24. Oh, D. et al. Biologically enhanced cathode design for improved capacity and cycle life for lithium-oxygen batteries. Nat. Commun. 4, 2756 (2013).

25. Ottakam Thotiy, M. M., Freunberger, S. A., Peng, Z. \& Bruce, P. G. The carbon electrode in nonaqueous $\mathrm{Li}_{-} \mathrm{O}_{2}$ cells. J. Am. Chem. Soc. 135, 494-500 (2013).

26. Lu, J. et al. A nanostructured cathode architecture for low charge overpotential in lithium-oxygen batteries. Nat. Commun. 4, 2383 (2013).

27. Black, R. et al. Screening for superoxide reactivity in $\mathrm{Li}-\mathrm{O}_{2}$ batteries: effect on $\mathrm{Li}_{2} \mathrm{O}_{2} / \mathrm{LiOH}$ crystallization. J. Am. Chem. Soc. 134, 2902-2905 (2012).

28. Chen, Y., Freunberger, S. A., Peng, Z., Barde, F. \& Bruce, P. G. Li- $\mathrm{O}_{2}$ battery with a dimethylformamide electrolyte. J. Am. Chem. Soc. 134, 7952-7957 (2012).

29. Freunberger, S. A. et al. The lithium-oxygen battery with ether-based electrolytes. Angew. Chem. Int. Ed. Engl. 50, 8609-8613 (2011).

30. Adams, B. D. et al. Current density dependence of peroxide formation in the Li$\mathrm{O}_{2}$ battery and its effect on charge. Energy Environ. Sci. 6, 1772-1778 (2013).

31. Li, F. et al. Ru/ITO: a carbon-free cathode for nonaqueous $\mathrm{Li}^{-\mathrm{O}_{2}}$ battery. Nano Lett. 13, 4702-4707 (2013).

32. Qin, Y. et al. In situ fabrication of porous-carbon-supported $\alpha-\mathrm{MnO}_{2}$ nanorods at room temperature: application for rechargeable $\mathrm{Li}_{-} \mathrm{O}_{2}$ batteries. Energy Environ. Sci. 6, 519-531 (2013).

33. Lim, H. K. et al. Toward a lithium-'air' battery: the effect of $\mathrm{CO}_{2}$ on the chemistry of a lithium-oxygen cell. J. Am. Chem. Soc. 135, 9733-9742 (2013).

34. Yilmaz, E., Yogi, C., Yamanaka, K., Ohta, T. \& Byon, H. R. Promoting formation of noncrystalline $\mathrm{Li}_{2} \mathrm{O}_{2}$ in the $\mathrm{Li}-\mathrm{O}_{2}$ battery with $\mathrm{RuO}_{2}$ nanoparticles. Nano Lett. 13, 4679-4684 (2013).

35. Xu, J. J., Wang, Z. L., Xu, D., Zhang, L. L. \& Zhang, X. B. Tailoring deposition and morphology of discharge products towards high-rate and long-life lithium-oxygen batteries. Nat. Commun. 4, 2438 (2013).

36. Black, R., Lee, J. H., Adams, B., Mims, C. A. \& Nazar, L. F. The role of catalysts and peroxide oxidation in lithium-oxygen batteries. Angew. Chem., Int. Ed. 52, 392-396 (2013).

37. Huang, X. et al. Carbon nanotube-encapsulated noble metal nanoparticle hybrid as a cathode material for Li-oxygen batteries. Adv. Funct. Mater. 24, 6516-6523 (2014)
38. Tian, F., Radin, M. D. \& Siegel, D. J. Enhanced charge transport in amorphous $\mathrm{Li}_{2} \mathrm{O}_{2}$. Chem. Mater. 26, 2952-2959 (2014).

39. Geng, W. T., He, B. L. \& Ohno, T. Grain boundary induced conductivity in $\mathrm{Li}_{2} \mathrm{O}_{2}$. J. Phys. Chem. C 117, 25222-25228 (2013).

\section{Acknowledgements}

This work was financially supported by the 100 Talents Programme of the Chinese Academy of Sciences, National Program on Key Basic Research Project of China (2012CB215500 and 2014CB932300), National Natural Science Foundation of China $(21422108,21271168$ and 51472232) and Strategic Priority Research Program of the Chinese Academy of Sciences (Grant No. XDA09010404).

\section{Author contributions}

X.B.Z., Q.C.L. and J.J.X. developed the concept. X.B.Z., Q.C.L, J.J.X. and D.X designed the experiments and wrote the manuscript.

\section{Additional information}

Supplementary Information accompanies this paper at http://www.nature.com/ naturecommunications

Competing financial interests: The authors declare no competing financial interests.

Reprints and permission information is available online at http://npg.nature.com/ reprintsandpermissions/

How to cite this article: Liu, Q.-C. et al. Flexible lithium-oxygen battery based on a recoverable cathode. Nat. Commun. 6:7892 doi: 10.1038/ncomms8892 (2015).

\section{(c) (i)}

This work is licensed under a Creative Commons Attribution 4.0 International License. The images or other third party material in this article are included in the article's Creative Commons license, unless indicated otherwise in the credit line; if the material is not included under the Creative Commons license users will need to obtain permission from the license holder to reproduce the material. To view a copy of this license, visit http://creativecommons.org/licenses/by/4.0/ 